\title{
TYPES OF COMMUNICATIVE BEHAVIOUR OF UKRAINIAN POLITICIANS (P. POROSHENKO, YU. TYMOSHENKO, V. YANUKOVYCH AND V. YUSHCHENKO)
}

\author{
Daria Kharytonova \\ Candidate of Philology, Taras Schevchenko National University of Kyiv, Ukraine \\ e-mail: darjakharytonova@gmail.com,orcid.org/0000-0003-4806-3572
}

\section{Summary}

The present study is devoted to the investigation of the main types of communicative behaviour in the Ukrainian political linguoculture. In the institutional political discourse types of communicative behaviour might be qualified as markers of status and the most powerful manipulative determinants. Its identification can only be made by deep analysis of manipulative metastrategies, tactics, and cognitive scenarios. The use of manipulative metastrategies and tactics in the institutional political discourse demonstrates that knowledge, emotions, and will of the addressee are being operated. Manipulative metastrategies and tactics are called to implement and realize the communicative goals and intentions of the I-speaker-politician. The classification of manipulative metastrategies and tactics proposed in this paper is processed in the framework of cognitive scenarios of their deployment. According to it, politicians could be attributed with conflict, conflict-neutral, conflict-cooperative, and cooperative-conflict types of communicative behaviour. The conflict type is represented by Yu. Tymoshenko. P. Poroshenko shows a conflict-cooperative type. The cooperative-conflict can be distinguished in V. Yanukovych. And V. Yushchenko has a conflict-neutral type of communicative behaviour.

Keywords: discourse, institutional political discourse, communicative metastrategy, communicative tactics, cognitive scenario.

\section{DOI: https://doi.org/10.23856/4004}

\section{Introduction}

Within the frames of the paper types of communicative behaviour of Ukrainian politicians in the institutional political discourse as dynamic markers of "influence" has been studied.

The relevance of the presented study is determined, firstly, by the need in the investigation of the multi-vector nature of political discourse, the specifics of its impact on people; secondly, by lack of the comprehensive studies of the Ukrainian institutional political discourse in cognitive and pragmatic dimensions; thirdly, by the lacuna in the study of the types of communicative behaviour characteristic for the politicians.

The purpose is to establish the features of the implementation of types of communicative behaviour of Ukrainian politicians in the political space of Ukraine.

Achieving the purpose involves solving the following tasks:

1) to substantiate the methodology of communicative personality;

2) to find out the essential characteristics of types of communicative behaviour in political discourse;

3) to develop the author's model of speech influence based on the classification of communicative strategies and tactics and to show their realization in the political speech of each of the investigated Ukrainian politicians; 
4) on the basis of the conducted analysis to make an attempt to characterize types of communicative behavior of the politicians.

The material of the paper consists of political texts (2018-2004), including statements, debates, public speeches, letters and videos of press conferences, interviews of Ukrainian politicians: P. Poroshenko, Yu. Tymoshenko, V. Yanukovych, V. Yushchenko. The whole number of material contains about 80,000 microtexts.

The institutional political discourse is one of the most powerful means of influence and persuasion in the modern political world, which determines to a great extend the mode of perception of political realities by the ordinary man. On the one hand, it reflects the general political life of the country, on the other hand, it manifests the struggle for power of certain political figures and groups of influence. That is why the institutional political discourse appears to be an expression of ideological orientations and interests of certain political forces.

\section{Communicative Personslity vs Politician}

In modern linguistics, there are different typologies of personality, identified based on the modes of realization of language. Thus, V. Krasnykh identifies four types of personality:

- a person who speaks is a person in speech activity;

- linguistic personality is a person who manifests himself in speech activity only under the conditions of possession of a certain set of knowledge and ideas that are stored in his linguistic consciousness;

- speech personality is a person who chooses and implements a certain strategy and tactics, as well as determines of linguistic and extralinguistic means of communication;

- communicative personality is a specific participant in a certain communicative act, which actually acts in this communication (Krasnykh, 2003: 50-51).

I. Golubovska defined the communicative personality as a specific manifestation of speech personality in a certain communicative way (Golubovska, 2008: 27).

A. Artyukhova determines that the type of communicative personality forms a set of lingual, paralingual, and extralingual characteristics (Artyukhova, 2014: 81). G. Matveeva interprets this concept as "a set of speech preferences of the speaker in specific situations to actualize certain intentions and strategies to influence on the listener" (Matveeva, 1999: 14). M. Kitaygorodska notes that the functional model of a communicative personality is its speech portrait (Kitaygorodska, 1995: 29).

A politician is, of course, a communicative personality. His figure can be characterized, on the one hand, as a set of all cognitive-speech subjects of his own discourse (the I-individual-speaker, politician is a unique speech personality) and, on the other hand, as a subject of institutional discourse (the I-social-speaker, politician is a representative of a certain social institution). As a speech personality, he realizes himself in discursive actions, which are transformed into a discursive personality, that reveals its individual characteristics: ethnic, professional, age, gender, etc. (Karasyk, 2002: 90).

M. Kitaygorodskaya identifies certain parameters of a politician's analysis. The first is the level of vocabulary. The researcher analyzes only the vocabulary that uses the individual. The second is the level of semantics (the focus is only on the words used by the author). Those levels are indicative because they make the person recognizable. And, the third one is pragmatical. All attention is paid to goals, communicative roles, which are formed only in a particular process of communication (Kitaygorodskaya, 1995: 10-15) 


\section{Communicative Behavior}

In the modern scientific world, it is distinguished that communicative behavior is a set of norms and traditions of communication of a particular person or group of people (Sternin, 2015). In other words, it's a way of interaction among people.

According to N. Formanovska, communicative behavior "is inherent to the participant of dialogic communication, who constantly takes into account the social and psychological characteristics of his partner, his speech intentions, hidden meanings and tactics" (Formanovska, 2005: 43). Therefore, according to this definition, part of communicative behavior is actually behavior of a person.

It is accepted to distinguish two main types of behavior in communication - cooperative and conflict (confrontational). However, it seems appropriate to qualify another one - neutral. Thus, A. Korolyova calls them three types of the strategic lines of speech behavior, noting that depending on the situation, participants choose completely different communication strategies and tactics. Accordingly, this choice is dictated by the intentions of communicators on a psychological level. Therefore, the speaker will be focused "on actively and independently pursuing their own goals / interests, without paying attention to the interests of the partner / partners, that are involved in the conflict. This is made to show the desire of one of the participants to impose his view and way of a solution to the problem, to affirm himself, without interacting" in a conflict situation (Korolyova, 2008: 51). From this point of view, the speaker will choose such strategies and tactics, in which aggression, domination, and discreditation are indicative.

In cooperative behavior, communicators try not to bring the situation to a conflict or resolve it peacefully. According to V. Dudchenko, the cooperative type of behavior can also be called constructive, as it uses all means of rational communication (Dudchenko, 2001: 52). Strategies and tactics of this type of behavior will be combined with cooperation, trust, and compromise.

Neutral speech behavior occupies an intermediate position between conflict and cooperation. Choosing this behavior, the communicator ignores his partner, who wants to bring the communicative situation to a conflict, and tries to interact with partners in order to minimize differences in their views (Korolyova, 2008: 52). According to that, the choice of strategies and tactics will depend on the degree of flexibility of the speaker and his desire to avoid any problematic situations, without being involved incooperation with the opponent.

\section{Ukrainian politicians vs types of behaviour}

P. Poroshenko, Yu. Tymoshenko, V. Yanukovych, and V. Yushchenko are the main figures in modern Ukrainian institutional political discourse. They have created a peculiar ideal and virtual manipulative space to get Ukrainians' be interested in their ideas.

Every politician uses different manipulative metastrategies and tactics in the institutional political discourse, which demonstrate all verbal resources of the addressee. Manipulative metastrategies and tactics are called to implement and realize the communicative goals and intentions of the I-speaker-politician.

The classification of manipulative metastrategies and tactics is processed in the framework of cognitive scenarios of their deployment and demonstrates the quantitative and qualitative indicators of the dominant features of the types of communicative behavior.

All our metastrategies and tactics are implemented either to create a positive image of the subject of the speech, or a negative representation of the opponent, which are often closely 
interrelated. Therefore, the cognitive scenario itself is extremely important as a direct development of the communicative situation.

The initial criterion of such classification is the mode of application of the manipulative strategy: if it is achieved by logical, rational means of argumentation - such strategy qualifies as a plus. Manipulative metastrategy minus is realized by those tactics which are opposed to rational proof (Kharytonova, 2018).

\section{Manipulation}

\section{Metastrategy plus}

- tactics of presenting objective information

- tactics of logical argumentation

- tactics of uniting with the opponent

\section{$\underline{\text { Metastretagy minus }}$}

- tactics of calling for honesty

- tactics of absolution

- tactics of accusation

- tactics of confirmation of one's position

- tactics of offending

- tactics of giving advice

- tactics of warning

- tactics of positive self-presentation

- tactics of dramatization

- tactics of irony and sarcasm

- tactics of distortion of information

- combined tactics

\section{Scenarios:}

positive self-presentation

theatrical action

negative representation

combined scenario

According to it, politicians could be attributed with a conflict, conflict-neutral, conflict-cooperative, or cooperative-conflict type of communicative behaviour.

It is revealed that within the conflict type of communicative behaviour the emotional and aggressive tactics are being used. This type is represented by Yu. Tymoshenko. Her political speech is characterized by the following tactics (44\%): tactics of giving advice, tactics of warning, tactics of absolution, tactics of calling for honesty, tactics of dramatization, tactics of positive self-presentation, tactics of accusation, tactics of irony and sarcasm, tactics of abasement, tactics of distortion of information, which are realized in 4 scenarios - positive self-presentation, theatrical action, negative representation of the opponent and combined scenario. According to this, conflict type of communicative behavior can be defined as pushy, rude, and bossy one.

The conflict-neutral type is characterized by those tactics that implement the intention of the politician only, on the one hand, to provide a piece of true information, and, on the other hand, to blame, insult and criticize his addressee. V. Yushchenko demonstrates this type. In his 
political speech, there are following tactics (24\%): tactics of logical argumentation, tactics of confirmation of one's position, tactics of calling for honesty, tactics of accusations, tactics of offending and combined tactics (simultaneous lowering of the opponent's social status and raising of one's own). Their functioning is evidenced only in 3 scenarios - logical proof (appeal to the ratio), positive self-presentation, and negative representation of the opponent. The politician does not cooperate with his opponent at all.

In the conflict-cooperative type of behavior, the tactics of the demonstration of the domination of the I-speaker over the opponent are implemented, although tactics demonstrating the wish to cooperate with him are also used. The conflict-cooperative type of behavior is represented by V. Poroshenko. There are tactics of presenting objective information, tactics of dramatization, and combined tactics (simultaneous lowering of the opponent's social status and raising one's own) in his political speech $(12 \%)$. They are realized in 3 different scenarios $-\log$ ical proof (appealing to the ratio), theatrical action, and combined scenario.

V. Yanukovych, who manifests the cooperative-conflict type of communicative behaviour, uses the tactics (20\%) of approaching to the opponent, but it is usually done in combination with the tactics of domination. There are tactics of presenting objective information, tactics of uniting with the opponent, tactics of confirming one's own position, tactics of removal of responsibility, tactics of non-acceptance of accusations in V. Yanukovych's speech, which can be identified in 3 scenarios - logical proof (appealing to the ratio), positive self-presentation and negative representation of the opponent. Thus, the politician of the cooperative-conflict type tries to relieve tension in communication but also shows his position in a light manner.

\section{Tactics in politicians' speeches}

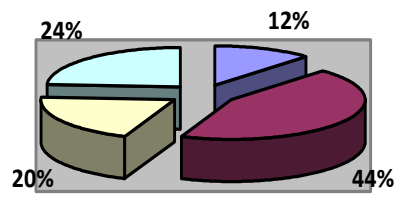

\begin{tabular}{|l|}
\hline$\square P$. Poroshenko \\
$\square Y u$. Tymoshenko \\
$\square$ V. Yanukovych \\
$\square$ V. Yushchenko
\end{tabular}

\section{Conclusions}

The results show that types of communicative behaviour of Ukrainian politicians can be identified during comprehensive contextual analysis. Only this analysis provides true information about the dominant features of each type. Cooperative, conflict, and neutral types of communicative behaviour cannot exist in modern institutional political discourse as they are. Depending on what and how a politician wants to achieve his communicative goal, he will hide his intensions using different metastrategies and tactics and modeling a favorable and actable communicative situation (scenario).

For the first time, a comprehensive methodology for studying Ukrainian's type of communicative behavior of institutional political discourse focused on the manifestation of its communicative-pragmatic features, qualifies it as a special set of communicative interactions among speakers, the prospects of which lie in a comparative aspect. Further analysis of the types of communicative behavior of other European politicians and their use of strategies and tactics can be investigated in comparison with other linguocultures. 


\section{References}

Artyukhova, A. A. (2014). Ahressyvnaia rytoryka kak persuazyvnui sposob v polytycheskoi kommunykatsyy (na materyale vblstuplenyi nemetskoho polytyka Hrehora Hyzy) [Aggressive rhetoric as a persuasive way in political communication (based on the material of the speeches of the German politician Gregor Gizi)]. Odessa: $M G U$. [in Russian]

Golubovska, I. O. (2008). Movna osobystist yak linhvokulturnyi fenomen. [Linguistic personality as a linguistic and cultural phenomenon]. Kyiv: Logos. [in Ukrainian]

Dudchenko, V. S. (2000). Transformatsyia konflykta. [Conflict transformation]. Moscow: RAN. [in Russian]

Karasyk, V. Y. (2002). Iazukovoi kruh: lychnost, kontseptbl, dyskurs. [Language circle: personality, concepts, discourse.]. Volhohrad: Peremena. [in Russian]

Kytaihorodskaia, M. V., Rozanova, N. N. (1995). Russkyi rechevoi portret: fonokhrestomatyia. [Russian speech portrait: phono-restomacy]. Moscow: Nauka. [in Russian]

Korolova, A. V. (2008). Stratehii i taktyky komunikatyvnoi povedinky uchasnykiv spilkuvannia $v$ sytuatsii konfliktu. [Strategies and tactics of communicative behavior of communication participants in a conflict situation]. Kyiv: Logos [in Ukrainian]

Krasnukh, V. V. (2003). "Svoi" sredy "chuzhykh": myf yly realnost? ["Self” among "aliens": myth or reality?]. Moscow: Gnozus. [in Russian]

Matveeva, G. G. (1999). Dyahnostyrovanye lychnostnblkh svoistv avtora po eho rechevomu povedenyiu. [Diagnosing the author's personality traits by his speech behavior]. Rostov-naDonu: DIuY [in Russian]

Sternyn, Y. A. (2015). Modely opysanyia kommunykatyvnoho povedenyia. [Models for describing communicative behavior]. Voronezh: Harant. [in Russian]

Formanovskaia, N. Y. (2005). Kultura obshchenyia y rechevoi etyket [Communication culture and speech etiquette]. Moscow: Ykar. [in Russian]

Kharytonova, D. D. (2018). Ukrainskyi politychnyi dyskurs: kohnityvno-semantychni ta prahmakomunikatyvni vymiry [Ukrainian Political Discourse: Cognitive and Pragmatic Dimensions]. Kyiv: Taras Schevnchenko University [in Ukrainian] 